\title{
The Metabolism of Lactate and Pyruvate by Pseudomonas AM1
}

\author{
By A. R. SALEM, C. WAGNER,* A. J. HACKING \\ AND J. R. QUAYLE \\ Department of Microbiology, University of Sheffield, Sheffield, S Io 2 TN
}

(Received 29 January 1973)

\begin{abstract}
SUMMARY
Pseudomonas AMI, which can grow on $\mathrm{C}_{1}$ compounds, also grows well on pyruvate and lactate. Extracts of the pyruvate-grown organism catalysed the synthesis of only small amounts of phosphoenolpyruvate directly from pyruvate. Experiments tracing the incorporation of radioactivity into bacterial constituents from pyruvate or lactate, each labelled in the C-I or C-3 position, indicated that these substrates are mainly assimilated after removal of the C-I atom. A mutant, C5, of Pseudomonas AMI was isolated by a procedure intended to select organisms lacking phosphoenolpyruvate carboxylase. Although this enzyme was present in mutant $\mathrm{C}_{5}$, growth on lactate or pyruvate was impaired and there was no growth on $\mathbf{C}_{1}$ compounds or ethanol. Good growth on each of these substrates was restored by a supplement of glyoxylate or glycollate.

A scheme is proposed for the assimilation via malate synthase and phosphoenolpyruvate carboxykinase of the $\mathrm{C}_{2}$ fragment produced from pyruvate and lactate.
\end{abstract}

\section{INTRODUCTION}

It has been shown that the formation of phosphoenolpyruvate from pyruvate is achieved in Enterobacteriaceae in vivo through the sole agency of phosphoenolpyruvate synthetase (Cooper \& Kornberg, 1967; Kornberg, 1970):

$$
\mathrm{CH}_{3} \cdot \mathrm{CO} \cdot \mathrm{CO}_{2} \mathrm{H}+\mathrm{ATP} \rightleftharpoons \mathrm{CH}_{2}: \mathrm{C}(\mathrm{OP}) \cdot \mathrm{CO}_{2} \mathrm{H}+\mathrm{AMP}+\mathrm{Pi} \text {. }
$$

The phosphoenolpyruvate can then be used for gluconeogenesis or, after carboxylation by phosphoenolpyruvate carboxylase, for the anaplerotic formation of $\mathrm{C}_{4}$ intermediates of the tricarboxylic acid cycle (Ashworth \& Kornberg, I966; Kornberg, 1970):

$$
\mathrm{CH}_{2}: \mathrm{C}(\mathrm{OP}) \cdot \mathrm{CO}_{2} \mathrm{H}+\mathrm{CO}_{2} \rightarrow \mathrm{HO}_{2} \mathrm{C} \cdot \mathrm{CH}_{2} \cdot \mathrm{CO} \cdot \mathrm{CO}_{2} \mathrm{H}+\mathrm{Pi} \text {. }
$$

Despite the presence of other enzymes capable of carboxylating pyruvate or phosphoenolpyruvate in vitro, behaviour of mutants lacking phosphoenolpyruvate carboxylase shows that it is this enzyme which effects the formation of $\mathrm{C}_{4}$ dicarboxylic acids under physiological conditions. Such mutants can be isolated on the basis of their inability to grow on glucose, glycerol, lactate or pyruvate except in the presence of a supplement of an intermediate of the tricarboxylic acid cycle or an amino acid related thereto.

In Pseudomonas ami the only enzyme capable of carboxylating a $\mathrm{C}_{3}$ compound to a $\mathrm{C}_{4}$ compound, which has so far been detected, is phosphoenolpyruvate carboxylase (Large, Peel \& Quayle, 1962). If growth of Pseudomonas AM I on lactate or pyruvate entails a similar process to that of the Enterobacteriaceae then this enzyme would play a similar anaplerotic

* Present address: Veterans Administration Hospital, Department of Microbiology, 1310 Twenty Fourth Avenue South, Nashville, Tennessee, 37203, U.S.A. 
role in synthesis of intermediates of the tricarboxylic acid cycle. Its role during growth on $\mathrm{C}_{1}$ compounds as sole carbon source will, however, depend on the mechanism of the net synthesis of glyoxylate from $\mathrm{C}_{1}$ units. It has been shown (see Quayle, 1972) that during growth of Pseudomonas AMI on $\mathrm{C}_{1}$ compounds, phosphoglycerate can be synthesized by a sequence of reactions, known as the serine pathway, effecting the overall transformation:

$$
\mathrm{HCHO}+\mathrm{CHO} . \mathrm{CO}_{2} \mathrm{H}+\mathrm{NADH}_{2}+\mathrm{ATP} \rightarrow \text { phosphoglycerate }+\mathrm{ADP}+\mathrm{NAD}^{+} \text {. }
$$

The mechanism of the net synthesis of glyoxylate from $C_{1}$ units is not known. Possible mechanisms include $(a)$ direct condensation of two $\mathrm{C}_{1}$ units or $(b)$ extension of the carbon skeleton of phosphoglycerate by at least one carbon atom followed by cleavage of the molecule to glyoxylate and a residual multicarbon molecule. An obvious possibility for extension of the phosphoglycerate skeleton, prior to cleavage, is by carboxylation of derived phosphoenolpyruvate. The role of phosphoenolpyruvate carboxylase would clearly be very different in these two cases. In mechanism (a) the enzyme would mediate merely the synthesis of oxaloacetate necessary for synthesis of those amino acids derived from the tricarboxylic acid cycle, e.g. aspartate and glutamate. Lack of the enzyme would lead to a requirement during growth on $\mathrm{C}_{1}$ compounds for small quantities of a tricarboxylic acid cycle intermediate or related amino acid. In mechanism $(b)$ the enzyme would be directly involved in regeneration of the glyoxylate necessary for operation of the main carbon assimilation pathway. Lack of the enzyme would lead to a requirement during growth on $\mathrm{C}_{1}$ compounds not only for small quantities of a tricarboxylic acid cycle intermediate but also for substrate quantities of glyoxylate.

The diagnostic potential of the different roles of phosphoenolpyruvate carboxylase in the metabolism of Pseudomonas AMI led us to attempt the isolation of mutants lacking this enzyme. Searches for such mutants were made by screening for the inability to grow on lactate unless supplemented with succinate. The results of this study show that Pseudomonas AMI grows on lactate or pyruvate by a different route from that used by Enterobacteriaceae and the significance of these findings with respect to $C_{1}$ and $C_{2}$ metabolism by the organism is discussed.

\section{Chemicals}

METHODS

$N$-Methyl- $N^{\prime}$-nitro- $N$-nitrosoguanidine was obtained from Koch-Light Laboratories Ltd, Colnbrook, Buckinghamshire. The following substrates, coenzymes and purified enzymes were purchased from Boehringer Corporation (London) Ltd, London W.5: phosphoenolpyruvic acid (tricyclohexylamine salt), pyruvic acid (sodium salt), 2-phosphoglyceric acid (trisodium salt), nicotinamide nucleotide coenzymes, ADP, ATP (disodium salt), CoA (from yeast), lactate dehydrogenase (from rabbit muscle), pyruvate kinase (from rabbit muscle), glutamate-oxaloacetate transaminase (from pig heart) and enolase (from rabbit muscle). 3-Phosphoglyceric acid (disodium salt) and thiamine pyrophosphate were from Sigma (London) Chemical Co. Ltd, London, S.W.6. Acetyl CoA was prepared by the method of Stadtman (1957). Phenylhydrazine $\mathrm{HCl}$ (Hopkin and Williams, Chadwell Heath, Essex) was twice recrystallized from aqueous ethanol before use.

Sodium $\left[\mathrm{I}^{14} \mathrm{C}\right]$ pyruvate, sodium $\left[3^{-14} \mathrm{C}\right]$ pyruvate and sodium $\left[{ }^{14} \mathrm{C}\right]$ bicarbonate were obtained from the Radiochemical Centre, Amersham, Buckinghamshire. $\left[{ }^{14} \mathrm{C}\right]$ Lactate was from New England Nuclear, Boston, Massachusetts, U.S.A. 
Maintenance and growth of organisms

Pseudomonas AMI (NCIB 9133) was maintained in slope culture on an inorganic salts medium (Jayasuriya, 1955) containing methylamine hydrochloride (50 $\mathrm{mm}$ ) and agar $(\mathrm{I} \cdot 5 \%, \mathrm{w} / \mathrm{v})$. The organism was subcultured monthly and stored at $4{ }^{\circ} \mathrm{C}$ after incubation for 3 to 4 days at $30^{\circ} \mathrm{C}$. Mutant strains were maintained similarly on medium containing succinate $(50 \mathrm{~mm})$ in place of methylamine hydrochloride. The organisms were grown in liquid culture at $30{ }^{\circ} \mathrm{C}$ as described by Heptinstall \& Quayle (1970) on carbon sources as indicated in the Results section. Growth was assessed by measuring the extinction of $650 \mathrm{~nm}$. (An extinction of $0 . \mathrm{I}$ corresponds to $36 \mu \mathrm{g}$ dry wt of organism $/ \mathrm{ml}$ over the extinction range o to $0 \cdot 6$.)

After growth of mutant strains for experimental use, samples were tested for the presence of revertants to wild-type by subculture in media containing lactate, methanol, ethanol or lactate + succinate.

Escherichia coli strain I I3-3 ( $\mathrm{NCIB} 8878$ ), a cobalamin/methionine auxotroph (Davis \& Mingioli, 1950), was a gift from Dr M. A. Foster, Microbiology Unit, Department of Biochemistry, University of Oxford.

\section{Isolation of mutants}

The procedure of Harder \& Quayle (I97I) was followed, using $N$-methyl- $N^{\prime}$-nitro- $N$ nitrosoguanidine for mutagenesis. The permissive growth medium for mutants contained lactate $(50 \mathrm{~mm})+$ succinate $(2 \mathrm{mM})$. For penicillin selection following mutagenesis and expression, the medium contained lactate $(50 \mathrm{~mm})$ as sole carbon source. Over three cycles of selection, benzylpenicillin was used up to a final concentration of $600 \mathrm{units} / \mathrm{ml}$ of medium.

\section{Growth responses of mutant strains}

Erlenmeyer flasks $(250 \mathrm{ml})$ fitted with optically matched side-arms and containing the medium under test $(40 \mathrm{ml})$ were inoculated with about $10^{7}$ bacteria from a 24 -h culture of a mutant grown on lactate + succinate. Growth was assessed by monitoring the extinction at $650 \mathrm{~nm}$.

\section{Preparation of bacteria-free extracts}

Ultrasonic extracts were prepared as described by Harder \& Quayle (I97I). The supernatant fluids after centrifuging at $20000 \mathrm{~g}$ for $30 \mathrm{~min}$ at $0{ }^{\circ} \mathrm{C}$ were used as a source of enzymes. For assays involving the use of NADH the supernatant liquid after further centrifugation at $100000 \mathrm{~g}$ for $\mathrm{I} \mathrm{h}$ at $4{ }^{\circ} \mathrm{C}$ was taken in order to avoid excessive interference by NADH oxidase activity.

\section{Protein determination}

Protein was measured by the Folin-Ciocalteu method as described by Lowry, Rosebrough, Farr \& Randall (I95I), with bovine serum albumin as standard.

\section{Enzyme assays}

All enzymes were assayed at $30^{\circ} \mathrm{C}$. Mixtures lacking a substrate or containing boiled extracts were used as controls. Spectrophotometric estimations were conducted with a Unicam SP I 800 double-beam spectrophotometer (Pye Unicam Ltd, Cambridge).

Phosphoenolpyruvate carboxylyase (orthophosphate-oxaloacetate carboxylyase [phosphorylating] EC.4.1.1.31). The procedure was based on the method of Large et al.(1962). The assay 
mixture contained in a final vol. of $2 \mathrm{ml}$ : tris $\mathrm{HCl}, \mathrm{pH} 8.6,100 \mu \mathrm{mol} ; \mathrm{MgCl}_{2}, \mathrm{I} \mu \mathrm{mol} ; 2-$ mercaptoethanol, $2 \mu \mathrm{mol}$; $\mathrm{NADH}_{2}, 3 \mu \mathrm{mol}$; phosphoenolpyruvate, $2 \cdot 5 \mu \mathrm{mol}$; sodium $\left[{ }^{14} \mathrm{C}\right.$ bicarbonate, $20 \mu \mathrm{mol}, 2.6 \mu \mathrm{Ci}$; and enzymatic extract, o to $0.5 \mathrm{mg}$ protein. After incubation for $30 \mathrm{~min}$, the reaction was stopped with absolute ethanol $(3 \mathrm{ml})$ and precipitated protein was removed by centrifugation $(5000 \mathrm{~g}$; I $\mathrm{min})$. Samples $(0.5 \mathrm{ml})$ of the supernatant fluids were transferred to aluminium planchets (diam. $25 \mathrm{~mm}$ ), $0 . \mathrm{I} \mathrm{ml} \mathrm{formic} \mathrm{acid}(90 \%, \mathrm{w} / \mathrm{v})$ was added and the mixture dried in a stream of warm air. The non-volatile radioactive fixation products were assayed with an end-window counter (type EHM2S) coupled with a scaler (type D657; Panax Equipment Ltd, Redhill, Surrey), which had an efficiency of $8 \%$ under the conditions used. After correction for background counts (about Io c.p.m.) enzyme activity was calculated from the initial specific radioactivity of the sodium $\left[{ }^{4} \mathrm{C}\right]$ bicarbonate.

Phosphoenolpyruvate synthetase. The initial rate of ATP-dependent removal of pyruvate was estimated by the method of Cooper \& Kornberg (1969).

Pyruvate kinase (ATP: pyruvate phosphotransferase, EC. 2.7.I.40). This enzyme was assayed spectrophotometrically according to the procedure of Bücher \& Pfleiderer (1955).

Pyruvate phosphate dikinase. Assay of the AMP- and pyrophosphate-dependent formation of pyruvate from phosphoenolpyruvate was modified from that described by Hatch \& Slack (1968). The reaction mixture contained in a final vol. of $\mathrm{I} \mathrm{ml}$; tris $\mathrm{HCl}, \mathrm{pH} \mathrm{8.2}$,

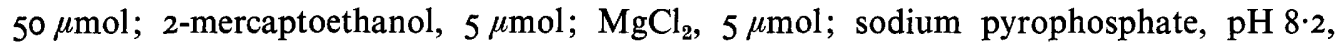
I. $2 \mu \mathrm{mol}$; AMP, $3 \mu \mathrm{mol}$; phosphoenolpyruvate, $2.5 \mu \mathrm{mol}$; $\mathrm{NADH}_{2}, 0.15 \mu \mathrm{mol}$; lactate dehydrogenase, $25 \mu \mathrm{g}$; and ultrasonic extract, I $\mathrm{mg}$ protein. The conversion to lactate of any pyruvate generated by the reaction mixture was followed by measuring the change in extinction at $340 \mathrm{~nm}$.

Phosphoenolpyruvate carboxykinase (ATP: oxaloacetate carboxylyase [transphosphorylating], EC. 4. I I . 32). This enzyme was assayed by a modification of the method of Herbert \& Guest (197I). The reaction mixture contained in a final vol. of $2 \mathrm{ml}$ : potassium phosphate buffer, $\mathrm{pH} 7 \cdot 0$, I00 $\mu \mathrm{mol}$; phosphoenolpyruvate, Io $\mu \mathrm{mol}$; ADP, $10 \mu \mathrm{mol} ; \mathrm{MnCl}_{2}$, Io $\mu \mathrm{mol}$; potassium L-glutamate, $20 \mu \mathrm{mol}$; sodium $\left[{ }^{14} \mathrm{C}\right]$ bicarbonate, $30 \mu \mathrm{mol}, 6.6 \mu \mathrm{Ci}$; glutamateoxaloacetate transaminase, 7.2 units; and enzymatic extract, o to $2.0 \mathrm{mg}$ protein. At $3 \mathrm{~min}$ intervals, samples $(0 . \mathrm{I} \mathrm{ml})$ were pipetted into $0.9 \mathrm{ml}$ formic acid (O.I M) in scintillation vials and left overnight at room temperature to remove dissolved ${ }^{14} \mathrm{CO}_{2}$. Water was added to a final vol. of $0.6 \mathrm{ml}$ followed by $6 \mathrm{ml}$ of liquid scintillator (xylene, $667 \mathrm{ml}$; Triton X-ıoo, $333 \mathrm{ml}$; 2, 5-diphenyloxazole, $5 \mathrm{~g}$; I,4-bis-(5-phenyloxazol-2-yl) benzene, $0.5 \mathrm{~g}$ ). The radioactivity was measured in a Nuclear-Chicago scintillation counter (Model 680I). Losses of phosphoenolpyruvate carboxykinase activity were reduced by the inclusion of glutathione (I mM) in buffer solutions (Utter, 196I). Controls lacking phosphoenolpyruvate or ADP were run with all experiments. These assay conditions were selected to minimize interference by phosphoenolpyruvate carboxylase. The latter reaction is $\mathrm{Mg}^{2+}$ ion-dependent with an optimum $\mathrm{pH}$ of 8.5 and is competitively inhibited by phosphate ions (Large $e$ t al. 1962). Fixation of $\mathrm{CO}_{2}$ in the absence of ADP never exceeded $25 \%$ of the total fixation and was deducted to give the activities quoted. It was possible to reduce this to $10 \%$ of total fixation by passage of extracts through G-25 Sephadex, but in these systems phosphoenolpyruvate carboxykinase activity was reduced to approximately $50 \%$ of the levels recorded without this treatment.

Pyruvate carboxylase (pyruvate: carbon dioxide ligase [ADP], EC. 6.4. I.1). The procedure described above for the estimation of phosphoenolpyruvate carboxylase was used, except that the reaction mixture contained ATP $(2 \mu \mathrm{mol})$ and phosphoenolpyruvate was replaced by sodium pyruvate $(5 \mu \mathrm{mol})$. 
Malate dehydrogenase (decarboxylating) (L-malate: NAD oxidoreductase [decarboxylating], $E C$. I. I. I .39). The ATP-independent fixation of ${ }^{14} \mathrm{CO}_{2}$ observed in the assay for pyruvate carboxylase was taken as a measure of malate dehydrogenase (decarboxylating) activity.

Phosphoglycerate mutase (2,3-diphospho-D-glycerate: 2-phospho-D-glycerate phosphotransferase, EC. 2.7.5.3). The reaction mixture contained in a final vol. of $3 \mathrm{ml}$ : tris $\mathrm{HCl}$, $\mathrm{pH} 7 \cdot 6,250 \mu \mathrm{mol} ; \mathrm{KCl}, 300 \mu \mathrm{mol} ; \mathrm{MgSO}_{4}, 75 \mu \mathrm{mol} ; \mathrm{NADH}_{2}, 0 \cdot 75 \mu \mathrm{mol} ; \mathrm{ADP}, 4 \mu \mathrm{mol}$; lactate dehydrogenase, I00 $\mu \mathrm{g}$; pyruvate kinase, $40 \mu \mathrm{g}$; phosphopyruvate hydratase, I00 $\mu \mathrm{g}$;3phosphoglycerate, $50 \mu \mathrm{mol}$; and ultrasonic extract, o to $3 \mathrm{mg}$ protein. Enzymatic activity was calculated from the decrease in extinction at $340 \mathrm{~nm}$ following the addition of 3-phosphoglycerate.

Phosphopyruvate hydratase (2-phospho-D-glycerate hydro-lyase, EC. 4.2.I.II). The formation of phosphoenolpyruvate from 2-phosphoglycerate was coupled to the oxidation of $\mathrm{NADH}_{2}$ in the following reaction mixture ( $3 \mathrm{ml}$ final vol.): tris $\mathrm{HCl}, \mathrm{pH} 7 \cdot 6,250 \mu \mathrm{mol}$; $\mathrm{KCl}, 300 \mu \mathrm{mol} ; \mathrm{MgSO}_{4}, 75 \mu \mathrm{mol}$; $\mathrm{NADH}_{2}, 0.75 \mu \mathrm{mol}$; ADP, $4 \mu \mathrm{mol}$; lactate dehydrogenase, $100 \mu \mathrm{g}$; pyruvate kinase, $40 \mu \mathrm{g}$; 2-phosphoglycerate, $5 \mu \mathrm{mol}$; and ultrasonic extract, 0 to $3 \mathrm{mg}$ protein. The reaction was followed at $340 \mathrm{~nm}$.

Malate synthase (L-malate glyoxylate-lyase [CoA-acetylating], EC. 4.1.3.2). This enzyme was assayed by the method of Dixon \& Kornberg (1962).

Pyruvate dehydrogenase (pyruvate: lipoate oxidoreductase [acceptor acylating], $E C$. I.2.4.1). The reduction of $\mathrm{NAD}^{+}$was estimated at $340 \mathrm{~nm}$ in the following reaction mixture (I ml final vol.): tris HCl, $\mathrm{pH} 8.5, \mathrm{I} 35 \mu \mathrm{mol}$; $\mathrm{CoA}, 88 \mathrm{nmol}$; L-cysteine $\mathrm{HCl}, 3.6 \mu \mathrm{mol}$; thiamine pyrophosphate, $240 \mathrm{nmol}$; NAD, $1.5 \mu \mathrm{mol}$; sodium pyruvate, $10 \mu \mathrm{mol}$; and ultrasonic extract, $0.0 \mathrm{I}$ to $0.5 \mathrm{mg}$ protein.

\section{Bacterial incorporation of $\left[{ }^{14} \mathrm{C}\right]$ lactate}

Lactate-grown Pseudomonas AMI was washed once with growth medium lacking a carbon source and resuspended in fresh lactate growth medium to give $100 \mathrm{mg} \mathrm{wet} \mathrm{wt} / \mathrm{ml}$. Samples $(2.25 \mathrm{ml})$ of the suspension were placed in each of two conical centrifuge tubes $(15 \mathrm{ml}$ capacity) and these were stirred rapidly at room temperature with magnetic stirrers. After $15 \mathrm{~min}$ of incubation, $0.45 \mathrm{ml}$ of each suspension was removed and pipetted into separate tubes containing $5 \mathrm{ml}$ absolute ethanol, $0.05 \mathrm{ml}$ sodium $\left[3^{-14} \mathrm{C}\right]$ lactate $(17 \mathrm{mM} ; 100 \mu \mathrm{Ci} / \mathrm{ml}$ ) was then added to one tube and $0.05 \mathrm{ml}$ sodium $\left[\mathrm{I}-{ }^{14} \mathrm{C}\right] \mathrm{lactate}(19 \mathrm{mM} ; 100 \mu \mathrm{Ci} / \mathrm{ml})$ to the other. These tubes served as controls. To the remaining suspensions $0.2 \mathrm{ml}\left[3^{-14} \mathrm{C}\right]$ lactate or $\left[\mathrm{I}^{14} \mathrm{C}\right]$ lactate solution was added respectively. Samples $(0.5 \mathrm{ml})$ were removed at 30 -second intervals and pipetted into separate tubes containing absolute ethanol $(5 \mathrm{ml})$. All samples were then treated in similar fashion. The ethanolic bacterial suspensions were centrifuged and the resulting precipitates extracted with $\mathrm{I} \mathrm{ml}$ of cold aq. $20 \%$ (v/v) ethanol. The combined supernatant fluids were evaporated to dryness in a stream of air at $50^{\circ} \mathrm{C}$. The residues were dissolved in $0.5 \mathrm{ml}$ of $0.0 \mathrm{I} \mathrm{M}-\mathrm{HCl}$ and applied to columns $(25 \mathrm{~mm} \times 5 \mathrm{~mm}$ diam.) of Dowex $50\left(\mathrm{H}^{+}\right.$form). The columns were washed with $10 \mathrm{ml}$ of water. The combined effluent and washings contained neutral and anionic compounds. The columns were then eluted with $4 \mathrm{ml}$ of $2 \mathrm{M}-\mathrm{NH}_{4} \mathrm{OH}$. The eluates which contained amino acids were evaporated to dryness and each dissolved in $0.1 \mathrm{ml}$ of water. The neutral/anionic fractions and the amino acid fractions were analysed by ion exchange chromatography and thin-layer chromatography (t.l.c.) as described below.

Chromatography and identification of labelled compounds. The neutral/anionic fractions obtained from the Dowex-50 columns were analysed by a modification of the method of von Korff (1969). The fractions were applied to columns $(1.5 \times 17 \mathrm{~cm})$ of Dowex-I 

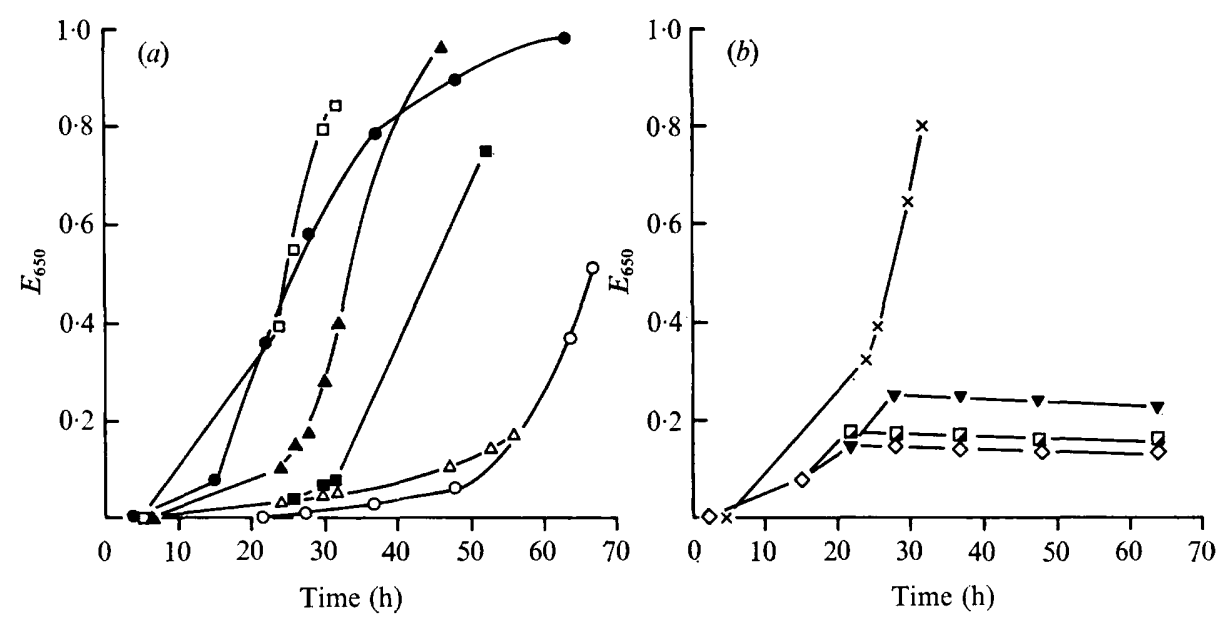

Fig. I. Influence of succinate on the growth of mutant $\mathrm{C}_{5}$ on $(a) \mathrm{C}_{3}$ compounds and $(b) \mathrm{C}_{1}$ and $\mathrm{C}_{2}$ compounds. For details of growth tests, see Methods section. Carbon sources for mutant $\mathrm{C}_{5}: \mathrm{O}$, pyruvate $(30 \mathrm{mM}) ; \boldsymbol{\theta}$, pyruvate, $(30 \mathrm{mM})+\operatorname{succinate}(0.5 \mathrm{mM}) ; \Delta$, lactate $(50 \mathrm{mM}) ; \boldsymbol{\Delta}$, lactate $(50 \mathrm{mM})+$ succinate $(0.5 \mathrm{mM}) ; \boldsymbol{\nabla}$, ethanol $(25 \mathrm{mM})+$ succinate $(0.5 \mathrm{~mm}) ; \nabla$, methanol $(0.5 \%, \mathrm{v} / \mathrm{v})+$ succinate $(0.5 \mathrm{~mm})$; $\diamond$, succinate $(0.5 \mathrm{~mm})$. Carbon sources for wild-type Pseudomonas AMI : $\square$, pyruvate $(30 \mathrm{mM}) ; \square$, lactate $(50 \mathrm{~mm}) ; \times$, methanol $(0.5 \%, \mathrm{v} / \mathrm{v})$.

(200 to $400 \mathrm{mesh} ; \times 8 ; \mathrm{Cl}^{-}$form) and eluted with $\mathrm{I} \cdot 5 \mathrm{mM}-\mathrm{HCl}$ at a rate of $35 \mathrm{ml} / \mathrm{h}$. Fractions of $5 \mathrm{ml}$ were collected. Lactate was eluted between fractions 30 and 40, followed closely by succinate. A linear gradient was formed from $400 \mathrm{ml}$ of $\mathrm{I} \cdot 5 \mathrm{mM}-\mathrm{HCl}$ and $400 \mathrm{ml}$ of $3.8 \mathrm{~mm}-\mathrm{HCl}$ and applied to the column. The radioactivity of the fractions was measured by adding $0.5 \mathrm{ml}$ samples to $10 \mathrm{ml}$ of Bray's solution (Bray, 1960) and assayed in a liquid scintillation counter. The identity of the organic acids obtained from the Dowex-I column was checked by t.l.c. on thin-layer microcrystalline cellulose plates using the upper phase of the solvent system: ethyl acetate + formic acid (90\%, w/v) + water $(60: 5: 35$, by vol.).

Amino acids were analysed by two-dimensional t.l.c. on microcrystalline cellulose plates using the solvent system of Kung \& Wagner (1970). The radioactive amino acids were located by autoradiography and assayed directly with a windowless gas-flow counter.

\section{RESULTS}

\section{Isolation and nutritional properties of mutants}

From a screening procedure designed to select mutants unable to grow on lactate (50 $\mathrm{mm}$ ) unless provided with a supplement of succinate $(2 \mathrm{mM})$, a group of auxotrophs was obtained which all possessed very similar nutritional properties. They were able to grow on succinate or malate as main carbon source but were apparently unable to grow on lactate or pyruvate unless supplemented with a small amount $(2 \mathrm{~mm})$ of succinate, malate, aspartate or citrate. They were not able to grow appreciably on methanol or ethanol, even when supplemented with 2 mM-succinate or malate. One mutant, C5, was investigated in detail.

The further studies of mutant $\mathrm{C}_{5}$ showed that it could indeed grow on lactate or pyruvate as sole carbon source but only slowly as compared with wild-type Pseudomonas AMI (Fig. I $a$ ). This effect was particularly marked with pyruvate as carbon source on which the wild-type organism grew well within $24 \mathrm{~h}$ at $30^{\circ} \mathrm{C}$, whereas growth of the mutant under the 
Table I. Activities of phosphoenolpyruvate carboxylase and phosphoenolpyruvate carboxykinase in bacteria-free extracts of wild-type and mutant Pseudomonas AM I

The enzymes were assayed as described in the Methods section.

Methanol $(0.5 \%, \mathrm{v} / \mathrm{v})$

Methanol $(0.5 \%, \mathrm{v} / \mathrm{v})+$ succinate (I mM)

Methylamine (50 mM)

Ethanol $(0.1 \%, \mathrm{v} / \mathrm{v})$

Lactate (50 mM)

Lactate $(50 \mathrm{~mm})+$ succinate $(\mathrm{I} \mathrm{mM})$

DL-Malate (O. I M)
Specific activity

( $\mu \mathrm{mol} \mathrm{CO}_{2} / \mathrm{min} / \mathrm{mg}$ of protein)

\begin{tabular}{|c|c|c|c|}
\hline \multicolumn{4}{|c|}{$\begin{array}{c}\text { Specific activity } \\
(\mu \mathrm{mol} \mathrm{CO} / \mathrm{min} / \mathrm{mg} \text { of protein })\end{array}$} \\
\hline \multicolumn{2}{|c|}{$\begin{array}{c}\text { Phosphoenolpyruvate } \\
\text { carboxylase }\end{array}$} & \multicolumn{2}{|c|}{$\begin{array}{c}\text { Phosphoenolpyruvate } \\
\text { carboxykinase }\end{array}$} \\
\hline Wild-type & Mutant C5 & Wild-type & Mutant C5 \\
\hline 0.13 & $0.088 *$ & 0.022 & - \\
\hline 0.087 & - & - & 一 \\
\hline 0.092 & - & 0.018 & - \\
\hline 0.018 & - & - & 一 \\
\hline 0.020 & - & 0.027 & 一 \\
\hline 0.022 & 0.018 & - & - \\
\hline - & - & 0.028 & 0.018 \\
\hline
\end{tabular}

* Organism first cultured in lactate $(50 \mathrm{~mm})+$ succinate $(\mathrm{I} \mathrm{mm})$ and then resuspended and shaken at $30^{\circ} \mathrm{C}$ for $12 \mathrm{~h}$ in medium containing methanol $(0.5 \%, \mathrm{v} / \mathrm{v})$.

same conditions was barely visible after this time. Repeated subculture showed that this slow growth on $\mathrm{C}_{3}$ compounds was not due to appearance of revertant strains. The addition of $0.5 \mathrm{~mm}$-succinate to the growth medium considerably increased the rate of growth on lactate or pyruvate. The slow rate of growth on lactate, coupled with the stimulation of growth by a supplement of succinate, probably explains how these mutants were selected by the enrichment procedure.

Mutant $\mathrm{C} 5$ was unable to grow on methanol or ethanol and addition of a supplement of $0.5 \mathrm{~mm}$-succinate to media containing these alcohols resulted in little more growth than did this amount of succinate alone (Fig. I $b$ ).

\section{Carboxylation of phosphoenolpyruvate}

The purpose of the mutant isolation procedure was to obtain mutants lacking phosphoenolpyruvate carboxylase. The growth properties of mutants, such as $\mathrm{c5}$, were suggestive of a dysfunction in this enzyme. However, extracts of mutant $\mathrm{c}_{5}$ grown on lactate supplemented with succinate contained phosphoenolpyruvate carboxylase at a specific activity comparable with that in the wild-type organism cultured in the same medium (Table I). In wild-type Pseudomonas AMI the specific activity of this enzyme varied with the growth substrate, being fivefold higher during growth on methanol or methylamine than on lactate or ethanol. Although mutant $\mathrm{C}_{5}$ was unable to grow on methanol, it was able to synthesize phosphoenolpyruvate carboxylase in response to exogenous methanol to the same extent as the wild-type organism. Hence mutant $\mathrm{c}_{5}$ appeared to have no lesion in synthesis of phosphoenolpyruvate carboxylase. Bacteria-free extracts of the malate-grown mutant also contained phosphoenolpyruvate carboxykinase at a specific activity of $60 \%$ that of wild-type (Table I).

\section{Activities of enzymes involved in $C_{3}$ and $C_{4}$ metabolism}

A further study (Table 2) of the enzymatic content of wild-type Pseudomonas AMI cast doubt on the validity of the initial premise upon which the mutant isolation procedure was based, viz. that anaplerotic formation of $\mathrm{C}_{4}$ intermediates of the tricarboxylic acid cycle is 
Table 2. Activities of enzymes associated with the metabolism of $C_{3}$ compounds by wild-type Pseudomonas AMI

Enzymes were assayed in crude ultrasonic extracts as described in the Methods section. Activities have been corrected for product formed in the presence of boiled extracts.

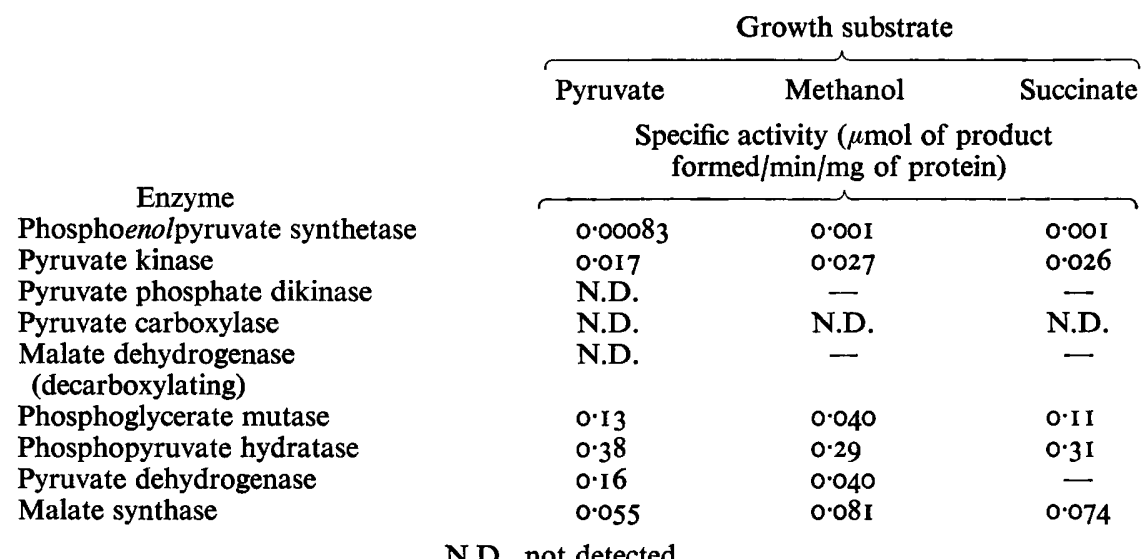

accomplished by the concerted operation of reactions (I) and (2). It is generally recognized that the formation of pyruvate from phosphoenolpyruvate, catalysed by pyruvate kinase:

$$
\mathrm{CH}_{2}: \mathrm{C}(\mathrm{OP}) \cdot \mathrm{CO}_{2} \mathrm{H}+\mathrm{ADP} \rightarrow \mathrm{CH}_{3} \cdot \mathrm{CO} \cdot \mathrm{CO}_{2} \mathrm{H}+\mathrm{ATP}
$$

is essentially irreversible under physiological conditions (see Cooper \& Kornberg, 1967; Kornberg, 1970). Hence, although Pseudomonas AMI contains pyruvate kinase, this enzyme would not be expected significantly to catalyse reaction (4) in the reverse direction. As the specific activity of this enzyme is lower during growth on pyruvate than on methanol or succinate this also argues against any special involvement during growth on pyruvate. Three routes are known which in other tissues can overcome the energy barrier associated with reversal of reaction (4): (a) the phosphoenolpyruvate synthetase reaction-reaction (I); (b) phosphorylation of pyruvate by means of pyruvate phosphate dikinase found in propionic acid bacteria (Evans \& Wood, I97I) and certain tropical grasses (Hatch \& Slack, I968):

$$
\mathrm{CH}_{3} \mathrm{CO} . \mathrm{CO}_{2} \mathrm{H}+\mathrm{ATP}+\mathrm{Pi} \rightleftharpoons \mathrm{CH}_{2}: \mathrm{C}(\mathrm{OP}) \cdot \mathrm{CO}_{2} \mathrm{H}+\mathrm{AMP}+\mathrm{PPi} \text {; }
$$

(c) carboxylation of pyruvate itself to malate or oxaloacetate, followed by formation of phosphoenolpyruvate from oxaloacetate by way of phosphoenolpyruvate carboxykinase:

$$
\mathrm{HO}_{2} \mathrm{C} \cdot \mathrm{CH}_{2} \cdot \mathrm{CO} \cdot \mathrm{CO}_{2} \mathrm{H}+\mathrm{ATP} \rightleftharpoons \mathrm{CH}_{2}: \mathrm{C}(\mathrm{OP}) \cdot \mathrm{CO}_{2} \mathrm{H}+\mathrm{ADP}+\mathrm{CO}_{2} \text {. }
$$

The rate of ATP-dependent removal of pyruvate, which is used as a measure of the activity of phosphoenolpyruvate synthase (Cooper \& Kornberg, 1969), was extremely low in extracts of Pseudomonas AMI and indeed no higher during growth on pyruvate as compared with methanol or succinate. The specific activity of $0.83 \mathrm{nmol} / \mathrm{min} / \mathrm{mg}$ of protein may be compared with $\mathrm{I} \cdot 7 \mu \mathrm{mol} / \mathrm{min} / \mathrm{mg}$ of protein found in lactate-grown Escherichia coli strain B (Cooper \& Kornberg, I969). No activity of pyruvate phosphate dikinase could be detected. Although phosphoenolpyruvate carboxykinase was found in extracts of Pseudomonas AMI (Table I) no activity of ATP-dependent pyruvate carboxylase or malate dehydrogenase (decarboxylating) could be detected (Table 2). Thus no enzymatic evidence could be found for appreciable overall conversion of pyruvate to phosphoenolpyruvate by routes $(a),(b)$ or (c) in extracts of Pseudomonas AmI even when grown on pyruvate. Nevertheless, phospho- 
pyruvate hydratase and phosphoglycerate mutase, which can convert phosphoenolpyruvate to other gluconeogenic substrates, were present in extracts (Table 2).

Such findings pointed to the operation of a novel route for synthesis of phosphoenolpyruvate (or gluconeogenic intermediates) and intermediates of the tricarboxylic acid cycle during growth of the organism on lactate or pyruvate. Recent work by Anthony and his colleagues (Anthony \& Dunstan, 1972; Dunstan \& Anthony, 1972; Dunstan, Anthony \& Drabble, $1972 a, b$ ) suggests that $P$ seudomonas AM I may possess a means of oxidizing acetate to glyoxylate, which would then enable the organism to grow on ethanol, malonate or $\beta$-hydroxybutyrate by the reactions shown in Scheme $\mathrm{I} a$. It is considered that each of these substrates is catabolized to acetate, or a derivative, which is then oxidized to glyoxylate. One molecule each of acetyl CoA and glyoxylate are in turn condensed to malate via malate synthase:

$$
\text { Acetyl CoA + glyoxylate }+\mathrm{H}_{2} \mathrm{O} \rightarrow \text { malate }+\mathrm{CoA} \text {. }
$$

Evidence for the acetate to glyoxylate transformation has been obtained from studies with intact bacteria and mutants but not, so far, with bacterial extracts.

If such a transformation can be effected by Pseudomonas AMI, then it clearly might offer an explanation for growth on pyruvate as the organism possesses both malate synthase and an active pyruvate dehydrogenase converting pyruvate to acetyl $\mathrm{CoA}$ (Table 2). These reactions could then provide for synthesis of malate from pyruvate (Scheme I $a$ ), and the action of malate dehydrogenase and phosphoenolpyruvate carboxykinase - reaction (6) could result in formation of phosphoenolpyruvate. Extracts of Pseudomonas AMI contain both malate dehydrogenase (Large, Peel \& Quayle, 1963) and phosphoenolpyruvate carboxykinase (Table I).

Evidence for operation of such a pathway (hereafter termed the malate synthase pathway) was then looked for in isotopic studies with intact bacteria.

\section{Incorporation of $\left[{ }^{14} \mathrm{C}\right]$ lactate into bacterial constituents}

The incorporation of $\left[\mathrm{I}^{14} \mathrm{C}\right]$ lactate and $\left[3^{-14} \mathrm{C}\right]$ lactate into Pseudomonas AM I growing on lactate was investigated. It was not possible to use paper chromatography and autoradiography to follow directly the time course of incorporation of tracer into metabolites owing to masking of the autoradiograms with residual radioactivity from unchanged lactate. Instead the samples were first separated into a neutral plus anionic fraction and a cationic fraction by ion exchange chromatography before being further analysed by ion exchange chromatography, t.l.c. and paper chromatography (see Methods section).

Two intermediates of the tricarboxylic acid cycle, malate and succinate, became labelled during incubation of Pseudomonas AMI with $\left[3^{-14} \mathrm{C}\right]$ lactate (Table 3 ). A number of other compounds, both neutral and anionic, became labelled but these were not identified. No radioactive malate or succinate was detected during the similar incubation with $\left[\mathrm{I}-{ }^{14} \mathrm{C}\right]$ lactate. This indicates that the $\mathrm{C}-\mathrm{I}$ atom of lactate is lost during conversion of lactate into $\mathrm{C}_{4}$ dicarboxylic acids whereas the $\mathrm{C}-3$ atom is retained. Such behaviour would be consistent with formation of malate by the malate synthase pathway but would not be consistent with formation of malate or oxaloacetate by carboxylation of pyruvate or phosphoenolpyruvate derived directly from pyruvate.

A variety of amino acids became labelled after incubation of Pseudomonas AMI with $\left[3^{-14} \mathrm{C}\right]$ lactate (Table 4$)$. The most rapidly labelled were glutamate, alanine and glycine. Incubation with $\left[\mathrm{I}^{-14} \mathrm{C}\right]$ lactate resulted in much less label appearing in amino acids, with the exception of alanine which was rapidly labelled in both cases. Equal labelling of alanine from either $\left[\mathrm{I}^{14} \mathrm{C}\right]$ lactate or $\left[3^{-14} \mathrm{C}\right]$ lactate is to be expected since alanine is probably formed 
Table 3. Incorporation of $\left[3^{-14} \mathrm{C}\right]$ lactate and $\left[\mathrm{I}^{14} \mathrm{C}\right]$ lactate into malate and succinate by Pseudomonas AMI growing on lactate

$\left[3^{-14} \mathrm{C}\right]$ Lactate or $\left[{ }^{-14} \mathrm{C}\right]$ lactate $(0.85 \mu \mathrm{mol}$ or $0.95 \mu \mathrm{mol}$ respectively; $5 \mu \mathrm{Ci})$ was added at zero time to $2.25 \mathrm{ml}$ of a suspension of bacteria $(100 \mathrm{mg}$ wet $\mathrm{wt} / \mathrm{ml}$ ) in lactate growth medium at room temperature. Samples $(0.5 \mathrm{ml})$ were removed at intervals into $5 \mathrm{ml}$ of absolute ethanol and centrifuged, the pellets were extracted with $\mathrm{I} \mathrm{ml}$ of aq. $20 \%(\mathrm{v} / \mathrm{v})$ ethanol. The neutral plus anionic fractions were analysed by ion exchange chromatography and t.l.c. as described in the Methods section.

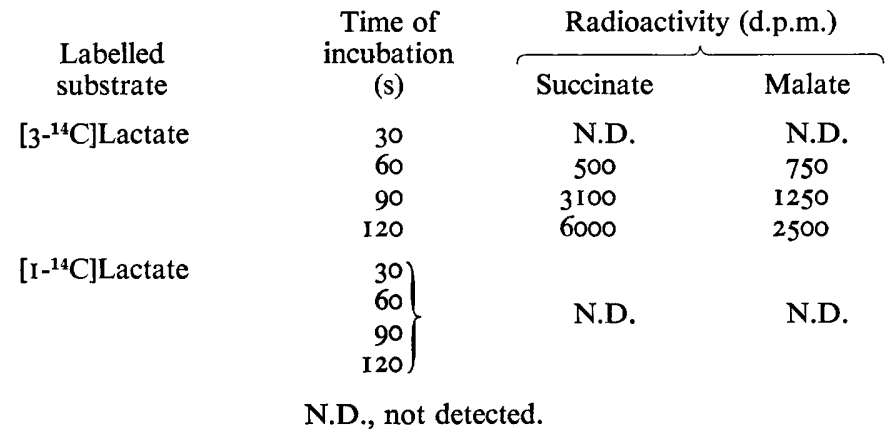

Table 4. Incorporation of $\left[3^{-14} \mathrm{C}\right]$ lactate and $\left[\mathrm{I}^{14} \mathrm{C}\right]$ lactate into amino acids by Pseudomonas AMI growing on lactate

The cationic fractions obtained from the experiments described in Table 3 were analysed by ion exchange chromatography and t.l.c. as described in the Methods section.

$\begin{array}{cccccccccccc}\begin{array}{c}\text { Labelled } \\ \text { substrate }\end{array} & \begin{array}{c}\text { Time of } \\ \text { incubation } \\ \text { (s) }\end{array} & \overbrace{\text { Glu }} & \text { Ala } & \text { Asp } & \text { Gln } & \text { Cys } & \text { Ser } & \text { Tyr } & \text { Met } & \text { Val } & \text { Gly } \\ {\left[3-{ }^{14} \text { C]Lactate }\right.} & 30 & 400 & 368 & - & - & - & - & - & - & - & 60 \\ & 60 & 1176 & 654 & 98 & 70 & 64 & 62 & 60 & 156 & - & 62 \\ & 90 & 3192 & 1606 & 158 & 100 & 84 & 96 & 72 & 58 & 118 & 96 \\ & 120 & 4840 & 2522 & 320 & 152 & 90 & 132 & 74 & 144 & 208 & 132 \\ {\left[\mathrm{I}-{ }^{14} \mathrm{C}\right] \text { Lactate }} & 30 & - & 530 & - & - & - & - & - & - & - & - \\ & 60 & - & 730 & - & - & 92 & - & - & - & - & - \\ & 90 & 80 & 1920 & - & - & 88 & 66 & - & - & - & 66 \\ & 120 & 90 & 2266 & 92 & - & 102 & 104 & 64 & 86 & - & 104\end{array}$

by amination of pyruvate derived from lactate. Aspartate is probably formed from amination of oxaloacetate and hence the lack of labelling of aspartate from $\left[\mathrm{I}^{14} \mathrm{C}\right]$ lactate again indicates that the $\mathrm{C}-\mathrm{I}$ atom of lactate is lost during conversion of lactate into $\mathrm{C}_{4}$ dicarboxylic acids.

Specific activity of cell material of Pseudomonas AMI and Escherichia coli grown on $\left[{ }^{\mathrm{I}}{ }^{14} \mathrm{C}\right]-$ pyruvate and $\left[3^{-14} \mathrm{C}\right]$ pyruvate

Operation of the proposed malate synthase pathway during growth of Pseudomonas AMI on lactate or pyruvate leads to formation of $\mathrm{C}_{4}$ dicarboxylic acids which are unlabelled from $\left[\mathrm{I}-{ }^{14} \mathrm{C}\right]$ lactate or $\left[\mathrm{I}-{ }^{14} \mathrm{C}\right]$ pyruvate and labelled from $\left[3^{-{ }^{14}} \mathrm{C}\right]$ pyruvate. In the absence of an enzyme which catalyses phosphorylation of pyruvate in vivo, phosphoenolpyruvate is probably made from oxaloaceate by means of reaction (6), and this again would be unlabelled from $\left[{ }^{\mathrm{I}}{ }^{14} \mathrm{C}\right]$ lactate or $\left[{ }^{[-14} \mathrm{C}\right]$ pyruvate and labelled from $\left[3^{-14} \mathrm{C}\right]$ lactate or $\left[3^{-14} \mathrm{C}\right]$ pyruvate. Hence all constituents derived from the tricarboxylic acid cycle and from phosphoenolpyruvate would be either unlabelled or labelled depending on whether the organisms were 
Table 5. Incorporation of radioactivity from $\left[\mathrm{I}^{14} \mathrm{C}\right]$ pyruvate and $\left[3^{-14} \mathrm{C}\right]$ pyruvate into growing cultures of Pseudomonas AMI and Escherichia coli

Cultures $(250 \mathrm{ml})$ were shaken at $30^{\circ} \mathrm{C}$ in Erlenmeyer flasks (I000 ml) fitted with side-arms for assessment of growth by extinction measurements at $650 \mathrm{~nm}$. The medium contained $\left[\mathrm{I}-{ }^{14} \mathrm{C}\right]$ pyruvate or $\left[3^{-14} \mathrm{C}\right]$ pyruvate $(\mathrm{I} \cdot 25 \mu \mathrm{Ci})$ and unlabelled pyruvate was added to a final concentration of $30 \mathrm{~mm}$. In addition, the medium for $E$. coli contained $0.1 \mathrm{mM} \mathrm{L}$-methionine. The inoculum was $\mathrm{I} \mathrm{ml}$ of a culture growing exponentially on pyruvate. A stream of moist, sterile air containing $\mathrm{CO}_{2}(2 \%, \mathrm{v} / \mathrm{v})$ was passed over the media throughout growth. Samples containing 0.25 to $0.65 \mathrm{mg}$ dry wt of organism were withdrawn at intervals and bacteria collected on a membrane filter previously washed with unlabelled pyruvate $(20 \mathrm{~mm})$. The bacteria were then washed with distilled water $(2 \times 5 \mathrm{ml}), 2 \mathrm{ml}$ of formic acid $(5 \%, v / v)$ to remove dissolved $\left[{ }^{14} \mathrm{C}\right]$ bicarbonate, and finally with distilled water $(5 \mathrm{ml})$. The filters were transferred to scintillation vials and covered with $5 \mathrm{ml}$ of scintillation fluid for estimation of radioactivity. The specific radioactivities given are the constant, maximum values obtained from samples taken between six and eight generations of growth on the labelled substrate.

$\begin{array}{cccc}\text { Labelled } & \begin{array}{c}\text { Specific } \\ \text { activity } \\ \text { Organism }\end{array} & \begin{array}{c}\text { (d.p.m. } / \mu \mathrm{g} \\ \text { substrate }\end{array} & \begin{array}{c}\text { Relative } \\ \text { specific } \\ \text { radioactivity }\end{array} \\ \text { Pseudomonas AM I } & {\left[3-{ }^{14} \mathrm{C}\right] \text { Pyruvate }} & 1 \mathrm{I} \cdot 06 & 5 \cdot 47 \\ \text { Escherichia coli } & {\left[\mathrm{I}-{ }^{14} \mathrm{C}\right] \text { Pyruvate }} & 2 \cdot 02 & \mathrm{I} \\ & {\left[3^{14} \mathrm{C}\right] \text { Pyruvate }} & 7 \cdot 33 & 2 \cdot 66 \\ & {\left[\mathrm{I}-{ }^{14} \mathrm{C}\right] \text { Pyruvate }} & 2 \cdot 76 & \mathrm{I}\end{array}$

grown on $\left[\mathrm{I}^{-14} \mathrm{C}\right]-$ or $\left[3^{-14} \mathrm{C}\right]$ lactate/pyruvate. This situation would contrast with that predicted for an organism such as Escherichia coli, which by virtue of phosphoenolpyruvate synthetase, would synthesize labelled phosphoenolpyruvate and labelled $\mathrm{C}_{4}$ dicarboxylic acids during growth on lactate/pyruvate labelled in either C-I or C-3. Hence the ratio of specific activity of cell material synthesized from $\left[3{ }^{14} \mathrm{C}\right]$ pyruvate to that synthesized from $\left[\mathrm{I}-{ }^{14} \mathrm{C}\right]-$ pyruvate should be considerably higher for an organism growing on pyruvate/lactate by the proposed malate synthase pathway than for an organism, such as $E$. coli, growing on the same substrate by the phosphoenolpyruvate synthetase pathway.

This prediction was verified in an experiment in which Pseudomonas AMI and Escherichia coli were each grown on $\left[33^{-14} \mathrm{C}\right]$ pyruvate and $\left[\mathrm{I}-{ }^{14} \mathrm{C}\right]$ pyruvate. Air, containing carbon dioxide $(2 \%, v / v)$, was continually flushed through the growth flasks so as to reduce incorporation of ${ }^{14} \mathrm{CO}_{2}$ derived from oxidation of the substrates. It can be seen (Table 5) that the ratio of the constant maximum specific radioactivity attained by Pseudomonas AMI on $\left[3-{ }^{14} \mathrm{C}\right]$ pyruvate to that attained on $\left[{ }^{1-14} \mathrm{C}\right]$ pyruvate was $5 \cdot 47$. This can be compared with a similar ratio of 2.66 obtained for $E$. coli in a similar experiment.

\section{Growth response of mutant $\mathrm{C} 5$ to glyoxylate and glycollate}

Mutant $\mathrm{C}_{5}$ was able to grow on a $\mathrm{C}_{3}$ compound alone, though appreciable growth only occurred several hours later than in a similar control culture of the wild-type organism (Fig. I a). Small amounts of succinate or other tricarboxylic acid cycle intermediates considerably stimulated growth of the mutant, especially with pyruvate as the major carbon source. In view of the evidence that during growth on a $C_{3}$ compound, the carbon source is metabolically linked to $\mathrm{C}_{4}$ dicarboxylic acids via $\mathrm{C}_{2}$ intermediates, the ability of glyoxylate or glycollate to replace succinate in enhancing the growth of mutant $\mathrm{C}_{5}$ on a $\mathrm{C}_{3}$ substrate was investigated. The stimulatory effects of small quantities of glyoxylate or glycollate were indeed comparable to those of succinate (Fig. 2a).

Mutant $\mathrm{C}_{5}$ possesses a metabolic lesion preventing growth on a $\mathrm{C}_{1}$ compound (Fig. $\mathrm{I} b$ ), 

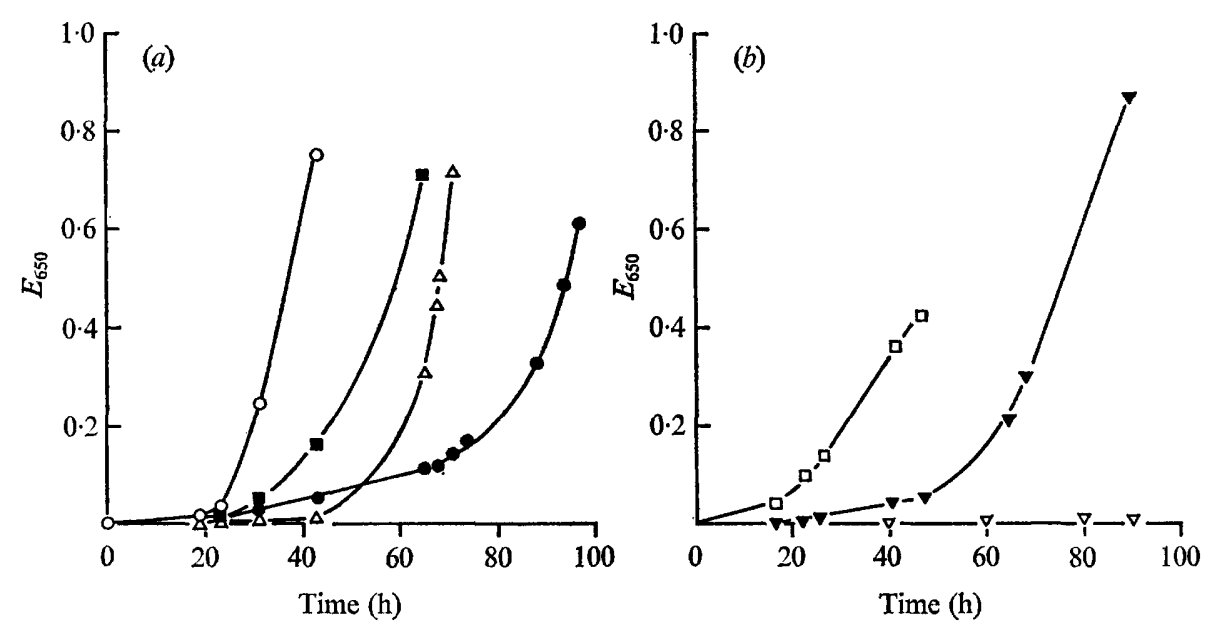

Fig. 2. Influence of glyoxylate and glycollate on the growth of mutant $\mathrm{C} 5$ on $(a) \mathrm{C}_{3}$ compounds and (b) methanol. For details of growth tests, see Methods section. Carbon sources: 9 , lactate (50 mM); D, lactate $(50 \mathrm{mM})+$ glyoxylate $(0.5 \mathrm{~mm}) ; \triangle$, pyruvate $(30 \mathrm{~mm}) ; 0$, pyruvate $(30 \mathrm{~mm})+$ glyoxylate $(0.5 \mathrm{~mm}) ; \nabla$, methanol $(0.5 \%, \mathrm{v} / \mathrm{v}), \nabla$, methanol $(0.5 \%, \mathrm{v} / \mathrm{v})+$ glyoxylate (IO $\mathrm{mM}) ; \square$, methanol $(0.5 \%, \mathrm{v} / \mathrm{v})+$ glycollate (IO mM).

and glycollate and glyoxylate were tested as supplements for growth on methanol as carbon source. Although small amounts of the $C_{2}$ supplements were rather ineffective, increasing their concentration to $10 \mathrm{~mm}$ permitted good growth (Fig. $2 b$ ). Neither glycollate nor glyoxylate alone (IO mM) supported measurable growth of either mutant $\mathrm{C}_{5}$ or wild-type Pseudomonas AMI.

\section{DISCUSSION}

The enzymatic content of Pseudomonas AMI and the results of the isotopic experiments point to a route for metabolism of lactate or pyruvate which differs fundamentally from that operating in Enterobacteriaceae. This novel route (Scheme $\mathrm{I} a$ ) would place lactate and pyruvate alongside ethanol, malonate and hydroxybutyrate as substrates catabolized to $\mathrm{C}_{2}$ units, from which acetyl CoA and glyoxylate are condensed by means of malate synthase to lead to the anaplerotic formation of $\mathrm{C}_{4}$ intermediates of the tricarboxylic acid cycle (Anthony \& Dunstan, 1972). The precise nature of the interconversions of $C_{2}$ units to give acetyl CoA and glyoxylate are not known, but glycollate may be involved.

It is now clear why the original mutant isolation procedure did not lead to isolation of mutants lacking in phosphoenolpyruvate carboxylase. There would not appear to be an important role for this enzyme during growth of Pseudomonas AMI on $\mathrm{C}_{3}$ compounds by Scheme $\mathrm{I}(a)$. This is borne out by the depressed specific activity of phosphoenolpyruvate carboxylase in the lactate-grown organism (Table $\mathrm{I}$ ). The actual lesion present in mutant $\mathrm{C}_{5}$ is not known, but its response to glycollate, glyoxylate or succinate suggests that it impaired in its ability to interconvert $\mathbf{C}_{2}$ units. This is further supported by the fact that it is unable to grow on ethanol.

Mutant C5 is unable to grow on methanol unless supplemented with glycollate or glyoxylate. It thus provides a further example of a mutant indicating a connexion between the pathways of assimilation of $\mathrm{C}_{1}$ and $\mathrm{C}_{2}$ compounds perhaps by way of glyoxylate or a com- 


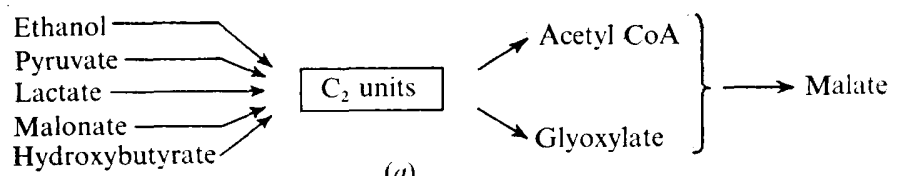

(a)

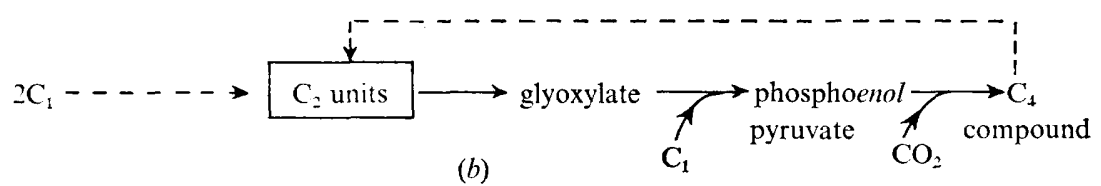

Scheme I. Possible involvement of $\mathrm{C}_{2}$ compounds in growth of Pseudomonas AmI on (a) compounds catabolized via acetate and $(b) C_{1}$ compounds. The boxes enclose interconversions of $C_{2}$ units at different oxidation levels between acetate and glyoxylate.

mon $\mathrm{C}_{2}$ precursor of glyoxylate. The other examples are PCT48 (Dunstan et al. $1972 b$ ) and G5 (Salem \& Quayle, I97I), both of which are unable to grow on either methanol or ethanol unless supplemented with glycollate or glyoxylate. Despite their similarity to mutant c5, both PCT 48 and G5 were selected for quite differently, viz. inability to grow on methanol but ability to grow on succinate (PCT48); inability to grow on methanol unless supplemented with glyoxylate (G5).

Scheme I $(b)$ expresses two ways in which glyoxylate might be synthesized in net fashion from $C_{1}$ units, either by direct $C_{1}+C_{1}$ condensation or by cleavage of a $C_{4}$ compound into two $C_{2}$ compounds both of which being converted into glyoxylate. Recent work by Salem, Large \& Quayle (I972) supports the latter mechanism rather than the former. The possible connexion between metabolism of $C_{1}$ compounds and compounds catabolized via acetate might then lie in the interconversion of $\mathrm{C}_{2}$ intermediary metabolites between the oxidation levels of acetate and glyoxylate. Lesions in enzymes involved in these interconversions would result in impaired ability to grow on both $C_{1}$ compounds and compounds catabolized via acetate.

The initial purpose of the work described in this paper, to isolate mutants of Pseudomonas AMI which lack phosphoenolpyruvate carboxylase, remains unfulfilled. These mutants would still be valuable for reasons outlined in the Introduction, but in view of the singular metabolism of $\mathrm{C}_{3}$ substrates by this organism it is clear that a different isolation procedure will have to be used. It may be necessary to find such mutants amongst those which are unable to grow on $\mathrm{C}_{1}$ compounds but able to grow on $\mathrm{C}_{4}, \mathrm{C}_{3}$ or $\mathrm{C}_{2}$ compounds.

This work was supported in part by Grant no. GB-6084 from the National Science Foundation, U.S.A. to C.W. and Grants no. B/SR/6038 and $B / R G / 27$ I I from the Science Research Council to J.R.Q.

\section{REFERENCES}

Anthony, C. \& Dunstan, P. M. (1972). A novel pathway for bacterial growth on malonate and $\beta$-hydroxybutyrate. Biochemical Journal r30, 30-3 I $P$.

Ashworth, J. M. \& Kornberg, H. L. (1966). The anaplerotic fixation of carbon dioxide by Escherichia coli. Proceedings of the Royal Society B 165, 179-1 88.

Bray, G. A. (1960). A simple efficient liquid scintillator for counting aqueous solutions in a liquid scintillation counter. Analytical Biochemistry I, 279-285. 
Bücher, T. \& Pfleiderer, G. (1955). Pyruvate kinase from muscle. In Methods of Enzymology, vol. I, pp. 435-440. Edited by S. P. Colowick and N. O. Kaplan. New York: Academic Press.

COOPER, R. A. \& KorNBerg, H. L. (1967). The direct synthesis of phosphoenolpyruvate from pyruvate by Escherichia coli. Proceedings of the Royal Society B 168, 263-280.

COOPER, R. A. \& Kornberg, H. L. (1969). Phosphoenolpyruvate synthetase. In Methods in Enzymology, vol. I 3, pp. 309-314. Edited by J. M. Lowenstein. New York and London: Academic Press.

Davis, B. D. \& Mingioli, E. S. (1950). Mutants of Escherichia coli requiring methionine or vitamin $\mathrm{B}_{12}$. Journal of Bacteriology 6o, $17-28$.

DiXon, G. H. \& KoRnBerg, H. L. (1962). Malate synthetase from baker's yeast. In Methods in Enzymology, vol. 5, pp. 633-637. Edited by S. P. Colowick and N. O. Kaplan. New York: Academic Press.

Dunstan, P. M. \& Anthony, C. (1972). Microbial growth on $C_{1}$ and $C_{2}$ compounds: the metabolism of acetate to glycine in Pseudomonas AMI. Biochemical Journal 130, 3I P.

Dunstan, P. M., Anthony, C. \& Drabble, W. T. (I972a). Microbial metabolism of $\mathrm{C}_{1}$ and $\mathrm{C}_{2}$ compounds. The involvement of glycollate in the metabolism of ethanol and of acetate by Pseudomonas AMr. Biochemical Journal 128, 99-106.

Dunstan, P. M., ANthony, C. \& Drabble, W. T. (1972b). Microbial metabolism of $C_{1}$ and $C_{2}$ compounds. The role of glyoxylate, glycollate and acetate in the growth of Pseudomonas AMI on ethanol and on $\mathrm{C}_{1}$ compounds. Biochemical Journal 128, 107-1 13.

Evans, H. J. \& Wood, H. G. (197I). Purification and properties of pyruvate phosphate dikinase from propionic acid bacteria. Biochemistry 10, $72 \mathrm{I}-728$.

HARDER, W. \& QuAYLE, J. R. (197I). The biosynthesis of serine and glycine in Pseudomonas AMI with special reference to growth on carbon sources other than $C_{1}$ compounds. Biochemical Journal 121, 753-762.

Hatch, M. D. \& Slack, C. R. (I968). A new enzyme for the interconversion of pyruvate and phosphopyruvate and its role in $\mathrm{C}_{4}$ dicarboxylic acid pathway of photosynthesis. Biochemical Journal ro6, 141146.

HePTinstall, J. \& Quayle, J. R. (1970). Pathways leading to and from serine during growth of Pseudomonas AMI on $\mathrm{C}_{1}$ compounds and succinate. Biochemical Journal II7, 563-572.

Herbert, A. A. \& Guest, J. R. (197I). Two mutations affecting utilization of $\mathrm{C}_{4}$-dicarboxylic acids by Escherichia coli. Journal of General Microbiology 63, I5I-I62.

JAYASURIYA, G. C. N. (1955). The isolation and characterictics of an oxalate-decomposing organism. Journal of General Microbiology 12, 419-428.

VON KoRFF, R. W. (1969). Ion exchange chromatography of citric acid cycle components and related compounds. In Methods in Enzymology, vol. 13, pp. 425-430. Edited by J. M. Lowenstein. New York and London: Academic Press.

KoRNBERG, H. L. (1970). Mechanisms of carbohydrate synthesis from $\mathrm{C}_{2}$-and $\mathrm{C}_{3}$-acids. In Miami Winter Symposium, vol. I, pp. 103-I2 I. Amsterdam: North-Holland Publishing Co.

KUNG, H. F. \& WAGNER, C. (1970). The enzymatic synthesis of $N$-methylalanine. Biochimica et biophysica acta 201, 513-516.

Large, P. J., Peel, D. \& Quayle, J. R. (1962). Microbial growth on $\mathrm{C}_{1}$ compounds. 4. Carboxylation of phosphoenolpyruvate in methanol-grown Pseudomonas AmI. Biochemical Journal 85, 243-250.

Large, P. J., Peel, D. \& Quayle, J. R. (1963). Microbial growth on $C_{1}$ compounds. 5. Enzyme activities in extracts of Pseudomonas AMI. Biochemical Journal 87, 386-396.

Lowry, O. H., Rosebrough, N. J., Farr, A. L. \& Randall, R. J. (I95I). Protein measurement with the Folin phenol reagent. Journal of Biological Chemistry 193, 265-275.

QUAYLE, J. R. (1972). The metabolism of one-carbon compounds in micro-organisms. In Advances in Microbial Physiology, vol. 7, pp. 1 19-203. Edited by A. H. Rose and D. W. Tempest. London and New York: Academic Press.

SAlem, A. R., Large, P. J. \& QuAYLe, J. R. (1972). Glycine formation during growth of Pseudomonas ami on methanol and succinate. Biochemical Journal 128, 1203-1211.

SALEm, A. R. \& QUAYLe, J. R. (197I). Mutants of Pseudomonas AmI that require glycollate or glyoxylate for growth on methanol or ethanol. Biochemical Journal 124, $74 \mathrm{P}$.

Stadtman, E. R. (1957). Preparation and assay of coenzyme A and other thiol esters: use of hydroxylamine. In Methods in Enzymology, vol. 3, pp. 931-94I. Edited by S. P. Colowick and N. O. Kaplan. New York: Academic Press.

UtTER, M. F. (196I). Non-oxidative carboxylation and decarboxylation. In The Enzymes, 2nd edn, vol. 5, pp. 337-338. Edited by P. D. Boyer, H. Lardy and K. Myrbäck. New York: Academic Press. 